\title{
PENGARUH JENIS PUPUK ORGANIK TERHADAP PERTUMBUHAN DAN HASIL TANAMAN BAWANG DAUN (Allium fistulosum L.)
}

\author{
Josina Hutubessy \\ irenehutubessy91@yahoo.co.id \\ Program Studi Agroteknologi, Fakultas Pertanian, Universitas Flores
}

\begin{abstract}
This research aims at investigating the effect of some organic fertilizers to the growth and yield of green onion plants. The kind of organic fertilizers which can give optimum growth and yield of green onion plants is Bokashi fertilizer. The design used in this experiment is Randomized Block Design (RBD). The treatment used are $\mathrm{P} 0=$ without fertilizer or $0 \mathrm{~kg}$ swath $^{-1}, \mathrm{P} 1=$ chicken manure 15 tons ha ${ }^{-1}$ or $2.4 \mathrm{~kg} \mathrm{swath}^{-1}, \mathrm{P} 2=$ cow manure 15 tons ha ${ }^{-1}$ or $2.4 \mathrm{~kg} \mathrm{swath}^{-1,} \mathrm{P} 3=$ vermicompost fertilizer 15 tons ha $^{-1}$ or $2.4 \mathrm{~kg}_{\text {swath }}{ }^{-1}$, $\mathrm{P} 4=$ bokashi fertilizer 15 tons $\mathrm{ha}^{-1}$ or $2.4 \mathrm{~kg}$ swath $^{-1}$. The observed variables are the height of the plants, the number of leaves, the leaf width, the number of seedlings, fresh residue $\tan ^{-1}$, the weight of fresh clump leaves $\tan ^{-1}$, the weight of fresh clump leaves ha ${ }^{-1}$, the number of clump stem ${ }^{-1}$, and the weight of clump stem ${ }^{-1}$. Bokashi fertilizer application gives a very real effect to the variable of plants height growth with a total of $37.91 \%$, the number of leaves amounted to $34.81 \%$, the leaves width amounted to $51.35 \%$, the number of seedlings amounted to $48.47 \%$, the fresh residue $\tan ^{-1}$ amounted to $44.81 \%$, weight of fresh clump leaves $\tan ^{-1}$ amounted to $19.27 \%$, the weight of fresh clump leaves ha ${ }^{-1}$ amounted to $50.84 \%$, the number of clump stem ${ }^{-1}$ amounted to $39.60 . \%$, and the weight of clump stem ${ }^{-1}$ amounted to $51.98 \%$. Kind of organic fertilizers which can provide the optimum growth and yield of green onion plants is Bokashi fertilizer 15 tons ha ${ }^{-1}$.

Key Words: kinds of bokashi fertilizer, green onion plants.

\section{PENDAHULUAN}

Bawang daun (Allium fistulosum L.)

merupakan salah satu jenis sayuran daun, bahan bumbu dapur dan pencampur sayur-mayur yang populer di Indonesia

yang paling penting dari bawang daun adalah daun-daun yang masih muda dan batang berwarna putih yang terpendam dalam tanah. Pada tiap 100 gram bawang daun mengandung kalori 29,00 kal,
\end{abstract} maupun di seluruh dunia. Bagian tanaman 
Josina: pengaruh jenis pupuk organik terhadap pertumbuhan dan hasil tanaman bawang daun (Allium fistulosum L.)

protein 1,80 gram, lemak 0,40 gram, karbohidrat 6,0 gram, serat 0,90 gram, abu 0,50 gram, kalsium 35,0 mg, fosfor $38,0 \mathrm{mg}$, zat besi $3,20 \mathrm{mg}$, vitamin A 910,0 SI, vitamin B1 0,08 mg, vitamin B2 0,09 mg, vitamin C 48,0 mg (Anonimus, 2006).

Bawang daun sistem perakarannya dangkal sehingga ketersedian hara pada lapisan harus selalu dipertahankan dengan penggunaan pupuk organik dan pupuk anorganik. Untuk dapat tumbuh dan berproduksi optimal, tanaman bawang daun membutuhkan unsur hara esensial selain radiasi surya, air dan $\mathrm{CO}_{2}$. Kandungan hara yang dibutuhkan oleh tanaman bawang daun yaitu: $\mathrm{N} 2,55 \%, \mathrm{P}$ 0,42\%, K 1,66\% (Laude dan Tambing, 2010).

Luas areal panen bawang daun Nasional tahun 20012 mencapai 55,611 ha atau menempati urutan ke 3 dari 18 jenis sayuran komersial yang dibudidayakan dan dihasilkan di indonesia. Dengan produksi 526.774 ton dan produktifitas 9.47 ton/ha (Badan Pusat Statistik Jakarta 2012). Propinsi Nusa Tenggara Timur (NTT) pada tahun 2011, luas areal panen tanaman bawang daun yakni 89 ha dengan produksi 202 ton dan produktifitas 2,27 ton/ha (Depertemen Pertanian dan Perkebunan Propinsi Nusa Tenggara Timur, 2012).Sedangkan di kabupaten Ende data produktifitas bawang daun belum ada informasi, karna masih sangat rendah petani di kabupaten Ende yang membudidayakan tanama bawang daun. Data tersebut menunjukkan bahwa produksi di NTT masih rendah. Salah satu penyebab produksi bawang daun yang rendah karena pemilihan jenis pupuk yang belum tepat. Pupuk dapat digunakan untuk meningkatkan ketersediaan unsur hara di dalam tanah sehingga tercapai produksi yang optimal (Hanafi, 2010).

Pupuk merupakan semua bahan yang ditambahkan ke dalam tanah dengan tujuan untuk meningkatkan kesuburan tanah, sehingga produksi tanaman dapat meningkat. Salah satu jenis pupuk yang dapat digunakan adalah pupuk organik. Pupuk organik adalah pupuk lengkap karena mengandung unsur makro dan mikro meskipun dalam jumlah sedikit. Penggunaan pupuk organik selama ini dapat mengatasi permasalahan yang ditimbulkan oleh pupuk anorganik, (Hanafi, 2010). Beberapa jenis pupuk 
Josina: pengaruh jenis pupuk organik terhadap pertumbuhan dan hasil tanaman bawang daun (Allium fistulosum L.)

organik yang dapat dimanfaatkan adalah seperti pupuk kandang ayam, pupuk kandang sapi, pupuk kascing dan pupuk bokasi.

Pupuk kandang ayam dapat meningkatkan kesuburan tanah dengan memiliki kandungan $\mathrm{N}$ yang cukup tinggi yakni : 2,6 \%, P 2,9 \%, dan K 3,4 \% dengan perbandingan $\mathrm{C} / \mathrm{N}$ rasio $8,3 \%$. Kandungan unsur hara dari pupuk kandang ayam lebih tinggi. Menurut Rahayu (2004) bahwa didalam kototan ayam terkandung unsur-unsur hara $\mathrm{N}, \mathrm{P}$, dan K. Ketiga kandungan unsur tersebut sangat penting bagi pertumbuhan dan perkembangan tanaman.

Pupuk kandang sapi merupakan pupuk padat yang banyak mengandung air dan lendir. Pupuk kandang sapi termasuk pupuk organik karena perubahan bahan yang terkandung didalam pupuk menjadi tersedia didalam tanah, berlangsung secara perlahan-lahan. Kandungan hara yang terdapat dalam pupuk kandang sapi adalah : N 1,11\%, P 1,62 \%, Kalium 7,26\%, Karbon organik $18,76 \%$, Kadar air $24,21 \%, \mathrm{C} / \mathrm{N}$ rasio $16,9 \%$ (Simanungkalit, 2006). Pemberian pupuk kandang sapi 15 ton ha $^{-1}$ dapat meningkatkan produksi tanaman bawang daun 3 ton $\mathrm{ha}^{-1}$. Pupuk kandang sapi merupakan pupuk organik yang dapat memperbaiki struktur tanah, meningkatkan daya pegang air, menambah unsur hara, meningkatkan kapasitas tukar kation dan meningkatkan mikroorganisme tanah (Hanafiah K.A).

Pupuk kascing merupakan pupuk organik yang dihasilkan oleh dekomposisi campuran limbah ternak dan sisa-sisa tanaman dengan prosesor utama cacing. Kandungan hara yang terdapat dalam pupuk kascing yaitu: $\mathrm{N}$ 0,5-2\%, $\mathrm{P}_{2} 0_{5}$ 0,06-0,08\%, K 0,10-0,68\%, kalsium 0,5$3,5 \%$ dan $\mathrm{C} / \mathrm{N}$ ratio $1,72 \%$. Hasil penelitian menyatakan bahwa penggunaan pupuk kascing dengan dosis 20 ton ha $^{-1}$ dapat menghasilkan berat basah gabah sebesar 14,522 ton ha-1.

Pupuk bokasih ini merupakan pupuk organik yang mudah dibuat dan dapat langsung diaplikasikan pada tanaman. Pemberian bokasih yang difermentasikan dengan EM-4 merupakan salah satu cara untuk memperbaiki sifat fisik, kimia dan biologi tanah serta dapat menekan hama dan penyakit serta meningkatkan mutu dan jumlah produksi tanaman (Nasir, 2008). Menurut Tata (2000) pupuk bokasih merupakan bahan- 
Josina: pengaruh jenis pupuk organik terhadap pertumbuhan dan hasil tanaman bawang daun (Allium fistulosum L.)

bahan organik yang difermentasikan menggunakan EM-4 dapat meningkatkan tanah yang miskin akan unsur hara menjadi tanah yang produktif melalui proses alamiah karena mengandung unsur hara yang lengkap. Mikroorganisme efektif (EM) merupakan kultur campuran berbagai jenis mikroorganisme yang bermanfaat (bakteri fotosintetik, bakteri asam laktat, ragi, actinomy-cetes dan jamur peragian) yang dapat dimanfaatkan sebagai inokulan untuk meningkatkan keragaman mikrobia tanah. Selanjutnya dikatakan bahwa mikroorganisme efektif (EM) yang hidup dalam bokasih mampu menggemburkan tanah sehingga ruang gerak akar tanaman menjadi lebih luas untuk tumbuh dan berkembang serta menyerap hara lebih baik. Pupuk organik bokasih dibuat dari bahan-bahan organik seperti jerami, sampah organik, pupuk kandang, sekam padi, rumput dan limbah jamur merang yang telah difermentasikan oleh mikroorganisme efektif (EM). Berdasarkan hasil penelitian untuk memperoleh pertumbuhan dan hasil tanaman bawang daun yang optimal di sarankan menggunakan pupuk $\mathrm{P}_{2} \mathrm{O}_{5} 115,2$ $\mathrm{kg} / \mathrm{ha}+$ Bokasih jerami limbah jamur merang 10 ton/ha (Nurlenawati, dkk, 2008).

\section{METODE PENELITIAN}

\section{Tempat dan Waktu percobaan}

Percobaan ini dilaksanakan di Desa Nanganesa, Kecamatan Ndona, Kabupaten Ende. Waktu percobaan Februari - Juni 2014. Kondisi tanah memiliki $\mathrm{pH}$ tanah 5,4 C-organik tergolong rendah dengan nilai $1,42 \%, \mathrm{~N}$ total tergolong rendah dengan nilai 0,15 $\%$, P-tersedia tergolong sedang dengan nilai 19,25 $\mathrm{mg}, \mathrm{K}$-tersedia tergolong tinggi dengan nilai $246,39 \mathrm{me} / 100 \mathrm{~g}$ dan memiliki tekstur tanah lempung berpasir.

\section{Bahan dan Alat}

Bahan yang diperlukan dalam penelitian ini adalah bibit bawang daun, jenis pupuk organik. Alat-alat yang digunakan terdiri atas tugal, ember, sembor, jangka sorong, hand cangkul, garpu, timbangan, mistar, kamera dan alat tulis.

\section{Rancangan Penelitian}

Rancangan yang digunakan dalam percobaan ini adalah Rancangan Acak Kelompok (RAK) dengan pola faktor tunggal yang terdiri dari lima perlakuan yaitu : 
Josina: pengaruh jenis pupuk organik terhadap pertumbuhan dan hasil tanaman bawang daun (Allium fistulosum L.)

$\mathrm{P}_{0}=0$ ton $\mathrm{ha}^{-1}$

$\mathrm{P}_{1}=$ Pupuk kandang ayam 15 ton ha ${ }^{-1}$

$\mathrm{P}_{2}=$ Pupuk kandang sapi 15 ton ha ${ }^{-1}$

$\mathrm{P}_{3}=$ Pupuk kascing 15 ton $\mathrm{ha}^{-1}$

$\mathrm{P}_{4}=$ Pupuk Bokasih 15 ton ha ${ }^{-1}$

Semua perlakuan diulang sebanyak 4 kali sehingga terdapat 20 petak percobaan.

\section{Variabel Penelitian}

Variabel yang diamati dalam penelitian ini adalah Tinggi tanaman rumpun ${ }^{-1}(\mathrm{~cm})$, Jumlah daun rumpun ${ }^{-1}$ (helai), Luas daun rumpun ${ }^{-1}\left(\mathrm{~cm}^{2}\right)$, Jumlah anakan $\tan ^{-1}$, Berat berangkasan segar $\tan ^{-1}(\mathrm{~g})$, Berat segar daun rumpun ${ }^{-1}(\mathrm{~g})$ dan berat segar daun $\mathrm{ha}^{-1}$ (ton), Jumlah batang rumpun ${ }^{-1}$ (g), dan Berat batang rumpun ${ }^{-1}(\mathrm{~g})$.

\section{HASIL DAN PEMBAHASAN}

\section{Hasil}

Hasil analisis statistik menunjukkan bahwa pengaruh pemberian dosis pupuk organik yang berbeda memberikan pengaruh yang sangat nyata terhadap seluruh variabel petumbuhann dan variabel hasil tanaman bawang daun pada setiap umur pengamatan.

\section{Pembahasan}

\section{Tinggi Tanaman, Jumlah Daun dan}

\section{Luas Daun}

Hasil analisis sidik ragam menunjukan bahwa pengaruh pemberian dosis pupuk organik yang berbeda terhadap pertumbuhan tanaman bawang daun memberikan pengaruh yang sangat nyata terhadap tinggi tanaman, jumlah daun dan luas daun pada setiap umur. Perlakuan jenis pupuk organik yang berbeda pada tanaman bawang daun memberikan pengaruh yang signifikan terhadap tinggi tanaman, jumlah daun dan luas daun tanaman bawang daun. Hal ini dapat terjadi karena pupuk organik merupakan penyumbang unsur hara yang kompleks bagi tanaman, serta dapat meningkatkan ketersediaan hara yang telah ada di dalam tanah (Hanafiah, 2010).

Perlakuan dosis pupuk bokasih sebanyak 15 ton ha ${ }^{-1}(\mathrm{P} 4)$ memberikan signifikasi peningkatan rataan total tinggi tanaman sebesar $37,91 \%$, jumlah daun sebesar 34,81\% dan luas daun sebesar $51,35 \%$ lebih tinggi dibandingkan dengan perlakuan pupuk organik lainya. Peningkatan variabel pertumbuhan membuktikan bahwa pupuk bokasih 
Josina: pengaruh jenis pupuk organik terhadap pertumbuhan dan hasil tanaman bawang daun (Allium fistulosum L.)

merupakan jenis pupuk organik yang dapat mendukung pertumbuhan tanaman bawang daun yang optimal kerena pupuk bokasih mengandung hara yang kompleks dan tersedia bagi tanaman. Selain itu, pupuk ini dihasilkan dari proses fermentasi atau peragian bahan organik dengan teknologi EM4 (Effective Microorganisms). Keunggulan penggunaan teknologi EM4 adalah pupuk organik (kompos) dapat dihasilkan dalam waktu yang relatif singkat dibandingkan dengan cara konvensional. EM4 sendiri mengandung Azotobacter sp, Lactobacillus sp, ragi, bakteri fotosintetik dan jamur pengurai selulosa. Kombinasi penyediaan hara serta keberadaan mikroorganisme tersebut menyebabkan pertumbuhan tanaman menjadi lebih baik (Djunaedy, 2009; Hanafiah, 2010).

Persentase peningkatan rataaan total tinggi tanaman, jumlah daun dan luas daun tanaman bawang daun yang paling rendah ditunjukkan oleh perlakuan tampa pupuk organik atau control (P0). Hal ini disebabkan karena kondisi tanah tempat diadakan penelitian memiliki kandungan organik tanah yang rendah sehingga tidak dapat mendukung pertumbuhan tanaman bawang daun yang optimal. Tanah yang subur dan mengandung hara yang cukup merupakan syarat mutlak bagi tanaman bawang daun.(Susila, 2006).

\section{Jumlah Anakan}

Hasil analisis sidik ragam menunjukkan bahwa pengaruh pemberian dosis pupuk organik yang berbeda memberikan pengaruh yang sangat nyata terhadap jumlah anakan tanaman bawang daun pada setiap umur pengamatan.

Perlakuan pupuk bokasih dengan dosis 15 ton $\mathrm{ha}^{-1}$ (P4) memberikan persentase rataan jumlah anakan tanaman bawang daun yang paling tinggi sebesar 48,47 \% di bandingkan dengan perlakuan lainya. Hal ini membuktikan bahwa pupuk bokasih merupakan jenis pupuk yang dapat mendukung perkembangan jumlah anakan tanaman bawang daun. Pemberian pupuk bokasi ke dalam tanah dapat memperbaiki sifat-sifat tanah (struktur tanah, porositas tanah, permeabilitas tanah) dalam hal meningkatkan kemampuan tanah untuk menahan air, sifat kimia tanah (meningkatkan kemampuan tanah untuk menyerap kation sebagai sumber hara 
Josina: pengaruh jenis pupuk organik terhadap pertumbuhan dan hasil tanaman bawang daun (Allium fistulosum L.)

makro dan hara mikro) dan sifat biologi tanah (meningkatkan aktivitas mikroba tanah dan sebagai sumber energi bagi bakteri). Pupuk bokasih dapat menaikan serapan hara NPK pada tanaman yang dibudidaya sampai $100 \%$ (Hanafiah, 2010). Pupuk organik merupakan suplement dengan bahan dasar yang diambil dari alam dengan jumlah jenis hara yang terkandung secara alami. Unsur hara yang terkandung secara alami tidak akan meninggalkan residu pada hasil tanaman. Hasil tanaman yang tidak mengandung residu aman bagi kesehatan dan lingkungan (Marsono dan Sigit, 2005). Perlakuan tanpa pemberian pupuk organik pada tanaman bawang daun memberikan persentase rataan total jumlah anakan yang paling rendah dibandingkan dengan perlakuan lainya yang menggunakan pupuk organik hal ini disebabkan karena kondisi tanah tempat tanaman dibudidaya. Bahan organik merupakan salah satu komponen tanah yang sangat penting bagi ekosistem tanah, dimana bahan organik merupakan sumber pengikat hara dan substrat bagi mikrobia tanah. Bahan organik tanah merupakan bahan penting untuk memperbaiki kesuburan tanah, baik secara fisik, kimia maupun biologi. (Hanafiah, 2010).

\section{Variabel Hasil}

Hasil analisis sidik ragam menunjukkan bahwa pengaruh pemberian dosis pupuk organik yang berbeda memberikan pengaruh yang sangat nyata berat brangkasan segar $\tan ^{-1}$, berat segar daun rumpun $\tan ^{-1}$, berat segar daun rumpun $\mathrm{ha}^{-1}$, jumlah batang rumpun ${ }^{-1}$ dan berat batang rumpun ${ }^{-1}$.

Perlakuan jenis pupuk organik yang berbeda terhadap faktor produksi tanaman bawang daun memberikan respon peningkatan masing-masing variabel hasil. Peningkatan pesentase rataan variabel hasil menujukkan bahwa perlakuan berbagai jenis pupuk organik yang berbeda meberikan respon pertumbuhan dan hasil pada tanaman bawang daun. Peningkatan persentase rataan total yang paling tinggi dari semua komponen variabel hasil ditunjukkan pada perlakuan pupuk bokasih dengan dosis 15 ton $\mathrm{ha}^{-1}$. Hal tersebut menujukkan bahwa pupuk bokasih merupakan jenis pupuk organik yang optimal untuk mendukung pertumbuhan dan hasil tanaman bawang daun. Hal ini 
Josina: pengaruh jenis pupuk organik terhadap pertumbuhan dan hasil tanaman bawang daun (Allium fistulosum L.)

karena di dalam pupuk bokasih terkandung unsur hara yang kompleks dan keberadaan pupuk bokasih dalam tanah dapat meningkatkan ketersediaan hara dalam tanah. Hal ini berhubungan dengan keberadaan asam-asam organik yang dapat menurunkan $\mathrm{pH}$ tanah (Hanafiah, 2010; Tan, 2003). Selain itu, humus dari pupuk bokasih dapat berperan sebagai koloid organik yang mengakibatkan ketersediaan hara dalam tanah (Hanafiah, 2010).

Perlakuan pupuk bokasih dengan dosis 15 ton ha ${ }^{-1}$ (P4) meningkatkan rataan total berat brangkasan segar $\tan ^{-1}$ sebesar 44,81 \%, berat segar daun rumpun $\tan ^{-1}$ sebesar $19,27 \%$, berat segar daun rumpun $\mathrm{ha}^{-1}$ sebesar 50,84\%, jumlah batang rumpun ${ }^{-1}$ sebesar 39,60\% dan berat batang rumpun ${ }^{-1}$ sebesar 51,98 $\%$. Peningkatan persentase semua variabel hasil membuktikan bahwa pupuk bokasih mempunyai daya untuk meningkatkan kesuburan tanah, mempertinggi kadar humus, mendorong kehidupan jasad renik dan menambah unsur hara mikro yang dibutuhkan oleh tanaman agar tetap terjadi keseimbangan unsur hara dalam tanah (Djunaedy, 2009).
Pupuk bokasih terbentuk dengan adanya penambahan EM4. Penambahan EM4 ini selain mempercepat proses dekomposisi, tapi juga meningkatkan keberadaan bakteri fotosisntesis dan pengikat nitrogen di dalam tanah. Keberadaan mikroorganisme ini dapat meningkatkan proses penyerapan hara serta produksi tanaman (Djuanedy, 2009).

\section{Kesimpulan}

1. Pemberian pupuk bokasih memberikan pengaruh sangat nyata terhadap variabel pertumbuhan tinggi tanaman sebesar $37,91 \%$, jumlah daun sebesar $34,81 \%$, luas daun sebesar 51,35 \%, jumlah anakan sebesar 48,47 \% brangkasan segar $\tan ^{-}$ ${ }^{1}$ sebesar $44,81 \%$, berat segar daun rumpun $\tan ^{-1}$ sebesar $19,27 \%$, berat segar daun rumpun $\mathrm{ha}^{-1}$ sebesar 50,84 $\%$, jumlah batang rumpun ${ }^{-1}$ sebesar $39,60 \%$ dan berat batang rumpun ${ }^{-1}$ sebesar $51,98 \%$.

2. Jenis pupuk organik yang dapat memberikan pertumbuhan dan hasil tanaman bawang daun yang opimal adalah pupuk bokasih 
Josina: pengaruh jenis pupuk organik terhadap pertumbuhan dan hasil tanaman bawang daun (Allium fistulosum L.)

\section{Ucapan Terima Kasih.}

Pada kesempatan ini penulis ingin mengucapkan terima kasih kepada semua pihak yang telah membantu dengan caranya masing-masing dalam melengkapi tulisan ini.

\section{DAFTAR PUSTAKA}

Anonimous. 2005, Kandungan tersebut bokasi mampu meningkatkan kesuburan tanah, memperluas pori. Jakarta

Anonimous. 2006. Petunjuk Bertanam Sayur. Aksi Agrasi Kanisius. Yayasan Kanisius Yogyakarta

Anonimous. 2007, Kelebihan lain dari pupuk bokasi ini, dengan formulasi bahan-bahan maka sangat mudah untuk mengontrol jumlah vitamin. Jakarta

Anonimous.2001.Bawangdaun.http://ww w.naturindonesia.com/tanaman pangan/tanaman buah dan sayuranb/635-bawang daun.html.Di unduh tanggl 14/09/2012 jam 07.56

BPS NASIONAL. 2007. Luas areal panen bawang daun Nasional tahun 2007

Departemen Pertanian Direktorat Jendral Bina Sarana Pertanian Direktorat Pupuk Dan Pesatisida. 2003

Deptan NTT, 2007. Luas areal panen bawang daun NTT tahun 2007. Ende dalam angka.
Djunaedy A. 2009. Pengaruh Jenis dan Dosis Pupuk Bokasi terhadap Pertumbuhan dan Hasil Kacang Panjang (Vigna sinensis L.). Agrovigor volume 2 (42-46).

Estu Rahayu. 1999. Perkembangan Bawang Daun, Erlangga, Jakarta.

Gardner. F.P.Pearce, B.,Mitchell, R. L., 1991. Fisiologi Tanaman Budidaya (Terjumahan H. Susilo). Universitas Indonesia Press, jakarta.

Hanafiah K.A. 2010. Dasar-Dasar Ilmu Tanah. PT Raja Grafindo Persada. Jakarta.

Nasi. 2008 http:angersatwiko.blogspot.com/20 11/09/pupuk-kandang-ayam.html. Kandungan Pada Pupuk Kandang Ayam.

Nasir. 2008. Pengaru Penggunaan Pupuk Bokasi pada Pertumbuhan dan Produksi Palawija dan sayuran.WWW disperternakpandeglang.go.id/artike 1 com Diunduh tanggal 31/Januari/2013/jam 16.34

Lamina. 2005. "Bawang Daun Mudah Diusahakan Besar Untungnya". Dalam: Swadesi Edisi 5 September 2005.

Laude S dan Tambing Y. 2010. Pertumbuhan dan Hasil Bawang Daun (Allium Fistulosum L.) pada berbagai Dosis Pupuk Kandang Ayam. J. Agroland 17(2): 144-148. 
Josina: pengaruh jenis pupuk organik terhadap pertumbuhan dan hasil tanaman bawang daun (Allium fistulosum L.)

Nurlenawati. N., dkk. 2010. Respon Pertumbuhan dan Hasil Tanaman Cabai Merah (capsicum annuum 1.) Varietas Prabu terhadap berbagai Dosis Pupuk Fosfat dan Bokasih Jerami Limbah Jamur Merang. J. Agrika. Volume 4 Nomor 1.

Mama Maya, 2011. Produksi Bawang Daun. Jakarta

Marsono dan Paulus Sigit, 2002. Manfaat Pupuk Tiens Golden Harves Pada Pertanian. Cv Aneka Ilmu

Rahkmat Rukmana, 2002. Kandungan Komposisi Gizi Bawang Daun, Agromedia Pustaka Jarta.

Purwa. $\quad$ D.R.,2009.Petunjuk pemupukan.Agro Media Pustaka. Jakarta.

Rahayu.2004.Pengaruh dosis pupuk kandang ayam terhadap pertumbuhan dan hasil tanaman bawang.htt://affandi 21. Xanga. Com/644038359/pemanfaatanayam-difermentasi-sebagai-nutrisi tanaman.di unduh tanggal 20 mey 2013 jam 19:30.

Rukmana.,R. 2008. "Budidaya tanaman sayuran. Seri Hortikultural” Dalam: bahan pelajaran Hortikultural di sekolah pertanian pembangunan (SPP), Maja-Majalengka.

Sugiharto. 2006. Budidaya Tanaman Bawang Daun, CV. Aneka Ilmu Semarang.

Saifudin Sarief. 1989. Teknik Budidaya Bawang Daun, Kanisius, Yogyakarta
Singgih Wibowo. 1992. Klasifikasi Bawang Daun, Kanisius, Yogyakarta

Soepardi. 1983. Nilai pupuk kandang ayam ditentukan oleh sumber penanganannya dan harga hara. Badan Penelitian dan Pengembangan Pertanian. Malang: Balai Penelitian Tanaman Kacangkacangan dan Umbi-umbian (Balitkabi).

Suardi. 2004, Penguji Kadar Nutrisi Pupuk Organik, Balai Besar Penelitian dan Pengembangan Bioteknologi dan Sumberdaya Genetik, Bogor.

Scullion, Malik dan Hendarsono. 2000, Pupuk Kascing, Cipanas, 29-30 Mei 1984. Jakarta

Santoso. 2008. Tanah merupakan sumber utama zat hara untuk tanaman dan tempat sejumlah perubahan penting dalam siklus produksi tanaman. Lembaran Informasi Pertanian. Balai Informasi Pertanian Bali.

Susila A.D. 2006. Panduan Budidaya Tanaman Sayuran. Bagian Produksi Tanaman Departemen Agronomi dan HoltikulturaInstitut Pertanian Bogor. Bogor

Trimulat. 2003. Kandungan Unsur Hara Pupuk Kandang Kascing. Balai Karantina Pertanian. Medan.

Tan Kim. 2003. Dasar-Dasar Kimia Tanah. Gajah Mada University Press. Yogyakarta.

Widayana.1996. Pupuk organik adalah pupuk lengkap karena 
Josina: pengaruh jenis pupuk organik terhadap pertumbuhan dan hasil tanaman bawang daun (Allium fistulosum L.)

mengandung unsur makro dan mikro.

http://www.nttprov.go.id/ntt_0

9/index.php?hal=pottani

Wibowo. S. 2009. "Menanam bawang daun Untungnya Merumpun. Dalam : Trubus, Info Agribisnis No. 23 TH.

Nopember 2009.
Widodo. 2008. kotoran ayam atau bahan organik merupakan sumber nitrogen tanah yang utama, Alam tani. http://www.alamtani.com/budi daya-kacang-tanahorganik.html. di akses 16 Juni 2013 